\title{
MANAJEMEN PEMASARAN PERSPEKTIF MAQASID SYARIAH
}

\author{
YAYAN FAUZI \\ STEBI Al Muhsin Yogyakarta \\ Email :yayasn@gmail.com
}

\begin{abstract}
Abstrak
Untuk mempertahankan kelangsungan perusahaan dan berkembangnya perusahaan maka suatu perusahaan membutuhkan manajemen pemasaran yang baik dan propesional. Dengan manajemen perusahaan yang baik ini diharapkan perusahaan mempunyai daya saing yang tinggi dan laba perusahaan akan selalu meningkat dan devidenpun meningkat.

Pengertian manajemen sendiri adalah proses perencanaan (Planning), pengorganisasian (organizing) penggerakan (Actuating) dan pengawasan, sedangkan pengertian pemasaran adalah analisis, perencanaan, implementasi, dan pengendalian dari program-program yang dirancang untuk menciptakan, membangun, dan memelihara pertukaran yang menguntungkan dengan pembeli sasaran untuk mencapai tujuan perusahaan.

Dalam ekonomi islam ada beberapa hal yang menjadi tujuan utama (maqasid syariah), tujuan utama ini harus dapat dipenuhi oleh semua perusahaan. hal ini menjadi penting karena di jadikan sebagai parameter atau ukuran bagaimana sebuah perusahaan itu bisa dikatakan syariah atau tidak.
\end{abstract}

Keywords : Manajemen Pemasaran dan Maqasid Syariah

\section{PENDAHULUAN}

Manajemen Pemasaran adalah salah satu kegiatan-kegiatan pokok yang dilakukan oleh perusahaan untuk mempertahankan kelangsungan perusahaannya, untuk berkembang, dan untuk mendapatkan laba. Kegiatan pemasaran perusahaan harus memberikan kepuasan kepada konsumen jika menginginkan usahanya berjalan terus, atau konsumen mempunyai pandangan yang lebih baik terhadap perusahaan.

Perusahaan yang sudah mulai mengenal bahwa pemasaran merupakan faktor penting untuk mencapai sukses usahanya, akan mengetahui adanya cara dan falsafah baru yang terlibat di dalamnya. Cara dan falsafah baru ini disebut "Konsep Pemasaran".

Didalam islam, pemasaran yang islami adalah bagaimana sebuah 
perusahaan dalam memasarkan produkproduknya mempunyai nilai dan etika islami. Nilai dan etika islam ini tentunya tidak terlepas dari (tujuan syariah) maqasid syariah. dimana nilai-nilai ini menggambarkan keunikan yang utama bagi pemasaran islam, bahkan dalam kenyataannya merupakan kekhasan yang bersifat menyeluruh yang tampak jelas pada segala sesuatu yang berlandaskan ajaran islam.

Dalam makalah ini akan dijelaskan bagaimanakah pengertian manajemen pemasaran berdasarkan maqasid syariah, kemudian bagaimanakah strategi pemasaran produk dan mempertahankan pelanggan dengan baik yang memenuhi maqasid syariah.

\section{A. Pengertian Maqasid Syariah dan} Manajemen Pemasaran

Maqashid al-syari'ah terdiri dari dua kata, maqashid dan syari'ah. Kata maqashid merupakan bentuk jama' dari maqshad yang berarti maksud dan tujuan, sedangkan syari'ah mempunyai pengertian hukum-hukum Allah yang ditetapkan untuk manusia agar dipedomani untuk mencapai kebahagiaan hidup di dunia maupun di akhirat. Maka dengan demikian, maqashid al-syari'ah berarti kandungan nilai yang menjadi tujuan pensyariatan hukum. Maka dengan demikian, maqashid al-syari'ah adalah tujuan-tujuan yang hendak dicapai dari suatu penetapan hukum. ${ }^{1}$

${ }^{1}$ Asafri Jaya, Konsep Maqashid al-Syari'ah Menurut al-Syathibi, Jakarta: Raja Grafindo Persada, 1996. hal.5.
Wahbah al-Zuhaili mendefinisikan maqashid syari'ah dengan makna-makna dan tujuan-tujuan yang dipelihara oleh syara' dalam seluruh hukumnya atau sebagian besar hukumnya, atau tujuan akhir dari syari'at dan rahasia-rahasia yang diletakkan oleh syara' pada setiap hukumnya. ${ }^{2}$

Menurut Yusuf Qardhawi Salah satu tujuan dari syariah (maqasid syariah) adalah adanya keadilan. Keadilan ini dalam artian si konsumen tidak dieksplotasi oleh suatu perusahaan dan perusahaan membuat produk yang menguntungkan buat konsumen. Sehingga antara perusahaan dan konsumen bisa saling menguntungkan.

Sedangkan pengertian Manajemen pemasaran Menurut Kotler dan Armstrong terdiri dari dua kata yaitu Pemasaran dan manajemen. pemasaran adalah analisis, perencanaan, implementasi, dan pengendalian dari program-program yang dirancang untuk menciptakan, membangun, dan memelihara pertukaran yang menguntungkan dengan pembeli sasaran untuk mencapai tujuan perusahaan. Sedangkan manajemen adalah proses perencanaan (Planning), pengorganisasian

(organizing) penggerakan (Actuating) dan pengawasan.

Jadi dapat diartikan bahwa Manajemen Pemasaran Menurut Kotler dan Armstrong adalah sebagai analisis, perencanaan, penerapan, dan pengendalian program yang dirancang untuk menciptakan, membangun, dan

${ }^{2}$ Wahbah al-Zuhaili, Ushul al-Fiqh al-Islami, Beirut: Dar al-Fikr, 1986, hal.1017. 
mempertahankan pertukaran yang menguntungkan dengan pasar sasaran dengan maksud untuk mencapai tujuantujuan organisasi. ${ }^{3}$

Kemudian kotler membagi definisi pemasaran menjadi dua yaitu definisi secara sosial dan definisi secara manajerial.

Definisi pemasaran secara sosial adalah proses sosial yang dengan proses itu individu dan kelompok mendapatkan apa yang mereka butuhkan dan inginkan dengan menciptkan, menawarkan dan secara bebas mempertukarkan produk dan jasa yang bernilai dengan pihak lain

Definisi pemasaran secara menejerial pemarsaran sering digambarkan sebagai seni menjual produk.

Menurut peter drucker tujuan pemasaran adalah mengetahui dan memahami pelanggan dengan baik sehingga produk atau jasa itu cocok dengan pelanggan dan selanjutnya mampu menjual dirinya sendiri. ${ }^{4}$

Didalam ensiklopedi ekonomi dan perbankan syariah, manajeman adalah proses perencanaan dan pengambilan keputusan, mengorganisasian, memimpin dan mengendalikan sumberdaya manusia, kenangan, fisik dan informasi guna mencapai sasaran organisasi dengan cara yang efektif dan efisien. ${ }^{5}$

Berdasarkan definisi di atas dapat dikatakan bahwa manajemen mengandung

http://ciku.typepad.com/blog/2009/12/definisipemasaran-dan-manajemen-pemasaran.html

${ }^{4}$ Philip kotler, Manajemen Pemasaran, hal. 10.

${ }^{5}$ Habib Nazir dan Muhammad Hasanuddin, 2008. Ensiklopedi ekonomi dan perbankan syariah, hal.415. empat komponen pokok yaitu perencanaan dan pengambilan keputusan (planing), pengorganisasian (organizing), kepemimpinan (actuating) dan pengendalian (controling).

Jadi dapat diartikan bahwa manajeman pemasaran berdasarkan maqasid syariah adalah sebagai analisis, perencanaan, penerapan, dan pengendalian program yang dirancang untuk menciptakan, membangun, dan mempertahankan pertukaran yang menguntungkan dengan pasar sasaran dengan maksud untuk mencapai tujuantujuan organisasi dengan memperhatikan keadilan antar konsumen dan perusahaan.

B. Maslahah dalam Maqasid syariah Masalahah dapat di bagi menjadi tiga tingkatan, yaitu:

1. Dharuriyat, yaitu maslahat yang bersifat primer, di mana kehidupan manusia sangat tergantung padanya, baik aspek diniyah (agama) maupun aspek duniawi. Maka ini merupakan sesuatu yang tidak dapat ditinggalkan dalam kehidupan manusia. Jika itu tidak ada, kehidupan manusia di dunia menjadi hancur dan kehidupan akhirat menjadi rusak (mendapat siksa). Ini merupakan tingkatan maslahat yang paling tinggi. Di dalam Islam, maslahat dharuriyat ini dijaga dari dua sisi: pertama, realisasi dan perwujudannya, dan kedua, memelihara kelestariannya. Contohnya, yang pertama menjaga agama dengan merealisasikan dan melaksanakan segala kewajiban agama, serta yang kedua menjaga kelestarian agama dengan berjuang 
dan berjihad terhadap musuh-musuh Islam.

2. Hajiyat, yaitu maslahat yang bersifat sekunder, yang diperlukan oleh manusia untuk mempermudah dalam kehidupan dan menghilangkan kesulitan maupun kesempitan. Jika ia tidak ada, akan terjadi kesulitan dan kesempitan yang implikasinya tidak sampai merusak kehidupan.

3. Tahsiniyat, yaitu maslahat yang merupakan tuntutan muru'ah (moral), dan itu dimaksudkan untuk kebaikan dan kemuliaan. Jika ia tidak ada, maka tidak sampai merusak ataupun menyulitkan kehidupan manusia. Maslahat tahsiniyat ini diperlukan sebagai kebutuhan tersier untuk meningkatkan kualitas kehidupan manusia. ${ }^{6}$

C. Strategi pemasaran produk

1. Siklus produk

a. Perkenalan (introduction) Periode pertumbuhan ini biasanya lembat dikarenakan produk baru diperkenalkan kepasar.

b. Pertumbuhan (growth) Periode ini biasanya pasar sudah bisa menerima produk sehingga dimungkinkan peningkatan laba yang cukup singnifikan.

c. Kedewasaan/ lematangan (maturity)

d. Penurunan (decline)
Periode dimana menunjukan arah yang menurun dan laba yang menipis. ${ }^{7}$ 
Tabel 1

Kurva siklus hidup produk



2. Hal-hal yang terlarang dalam bisnis syariah

a. Gharar (Penipuan)

Suatu akad yang mengandung unsur penipuan karena tidak ada kepastian, baik atau tidaknya objek akad, besar kecilnya jumlah, maupun kemampuan menyerahkan objek yang disebutkan dalam akad tersebut. ${ }^{8}$

b. Maisir (Gambling)

Alquran melarang secara tegas segala bentuk perjudian (QS. 5:9091). Alquran menggunakan kata maysir untuk perjudian, berasal dari kata usr (kemudahan dan kesenangan). penjudi berusaha mengumpulkan harta tanpa kerja dan saat ini istilah itu diterapkan secara umum pada semua bentuk aktivitas judi ${ }^{9}$

c. Riba (Bunga)

Riba menurut pengertian bahasa berarti (az-ziyadah) berkembang (an-numuw), meningkat (al-irtifa), dan membesar (al-uluw). Dengan kata lain riba adalah penambahan, perkembangan, peningkatan dan pembesaran atas pinjaman pokok yang diterima pemberi pinjaman dari peminjam sebagi imbalan karena menangguhkan atau berpisah dari sebagian modalnya selma periode waktu tertentu. ${ }^{10}$ Adapun larangan riba ada terdapat pada Al-quran surat (Al-baqarah (2): 278-279) dan surat (Ali-imron (3): 130)
${ }^{8}$ Habib Nazir dan Muhammad Hasanuddin, 2008. Ensiklopedi., hal. 245.
${ }^{9} \mathrm{http}: / /$ salmanitb.com/2010/02/prinsip-prinsipdasar-ekonomi-syariah/

${ }^{10}$ Hari sudarsono, Bank dan Lembaga Keuangan Syariah, hal. 10. 
d. Haram (Komoditi)

Haram adalah sesuatu yang dilarang mengerjakannya. Menurut imam gazali haram adalah sesuatu yang dituntut oleh syar'i untuk ditinggalkan melalui tuntutan secara pasti dan mengikat. ${ }^{11}$

e. Dzalim (Aniaya)

Adalah meletakkan sesuatu/ perkara bukan pada tempatnya. Di dalam al-Qur'an menggunakan kata zhulm selain itu juga digunakan kata baghy, yang artinya juga sama dengan zalim yaitu melanggar haq orang lain. Kalimat zalim bisa juga digunakan untuk melambangkan sifat kejam, bengis, tidak berperikemanusiaan, suka melihat orang dalam penderitaan dan kesengsaraan, melakukan kemungkaran, penganiayaan, kemusnahan harta benda, ketidak adilan.

f. Risywah (Suap)

Berasal dari kata bahasa arab rasya, yarsyu, rasywan, yang berarti sogokan, bujukan suap atau disebut dengan uang pelicin. Menurut ali bin muhammad as sayyid as syarif al jurjani riswa adalah sesuatu pemberian kepada seseorang untuk membatalkan sesuatu hak (benar) atau membenarkan yang batil. ${ }^{12}$

g. Maksiat (porno aksi, sex komersial,).

${ }^{11}$ Rahman Ritonga dkk, (2001). Ensiklopedi Hukum Islam, jilid 2, hal. 523

${ }^{12}$ Ibid, hal. 574.
Maksiat berarti durhaka, tidak patuh atau sesuatu perbuatan yang tidak mengikuti apa yang telah digariskan oleh Allah SWT. ${ }^{13}$

\section{Perilaku konsumen}

Bidang ilmu perilaku konsumen mempelajari cara individu, kelompok dan organisasi memilih, membeli, memakai, serta memanfaatkan barang, jasa, gagasan, atau pengalaman dalam rangka memuaskan kebutuhan dan hasrat mereka.

Memahami perilaku konsumen dan pelanggan bukan masalah yang sederhana. Para pelanggan mungkin menyatakan kebutuhan dan keinginan mereka namun bertindak sebaliknya. Para pelanggan tersebut mungkin tidak memahami motivasi mereka yang lebih dalam. Mereka mungkin menanggapi perngaruh yang mengubah pikiran mereka pada menit-menit terakhir.

Adapun analisis tentang konsumen bisa dilihat dari:

a. Faktor budaya

Dalam kelas sosial sangatlah penting bagi perilaku pembeli karena budaya merupakan penentu keinginan dan perilaku yang sangat besar.

1. Kultur (kebudayaan)

Kultur adalah determinan paling fundamental dari keinginan dan perilaku seseorang.

2. Sub-Kultur jilid 4, hal. 1088 .

${ }^{13}$ Rahman Ritonga dkk, (2001).Ensiklopedi., 1088. 
Setiap kulturterdiri dari sub-sub kultur yang lebih kecil yang emberikan identifikasi dan sosialisasi anggotanya yang lebih spesifik.

\section{Kelas Sosial}

Kelas sosial adalah bagianbagian yang relatif homogen dan tetap dalam suatu masyarakat, yang tersusun secara hirarkis dan anggota-anggotanya memiliki tata nilai, minat dan perilaku yang mirip.

b. Faktor sosial

Selain faktor budaya, perilaku konsumen dipengaruhi oleh faktor-faktor sosial seperti kelompok acuan, keluarga, serta peran dan status sosial.

1) Kelompok acuan

Kelompok acuan seseorang terdiri dari semua kelompok yang mempunyai pengaruh langsung atau pengaruh tidak langsung terhadap pendirian atau perilaku seseorang. Semua ini adalah kelompok di mana orang tersebut berada atau berinteraksi. Sebagian merupakan kelompok primer yang mana orang tersebut secara terus menerus berinteraksi dengan mereka. Seseorang juga termasuk dalam kelompok sekunder yang mana cenderung bersifat formal dan mempunyai interaksi yang tidak begitu rutin.
2) Keluarga

Orentasi keluarga terdiri dari orang tua seseorang.

3) Peran dan Status

Seseorang berpartisipasi dalm banyak kelompok sepanjang hidupnya, posisi orang tersebut dalam setiap kelompok dapat didefinisikan dalam istilah peran dan status.

c. Faktor pribadi

Karakteristik faktor pribadi meliputi usia, dan tahap siklus hidup, pekerjaan, keadaan ekonomi, gaya hidup serta keperibadian dan konsep diri pembeli.

1) Usia dan Tahap Siklus Hidup Orang-orang membeli barang dan jasa yang berbeda sepanjang hidupnya.

2) Pekerjaan

Pekerjaan seseorng mempengaruhi pola konsumsinya.

3) Keadaan Ekonomis

Keadaan ekonomi meliputi pendpatan yang dapat dibelanjakan (tingkat pendapatan, stabilitas dan pola waktunya), tabungan dan kekayaan, hutang, kekuatan untuk meminjam, dan pendirian terhadap belanja dan menabung.

4) Gaya Hidup 
Orang-orang yang berasal dari sub kultur, kelas social dan pekerjaan yang sama mungkin saja mempunyai gaya hidup yang berbeda.

5) Kepribadian dan Konsep Pribadi

Kepribadian didefinisikan sebagai karakteristik psikologis yang berbeda dari seseorang yang menyebabkan tanggapan yang relative konsisten dan tetap terhadap lingkungannya.

d. Faktor psikologi

Pilihan pembelian seseorang dipengaruhi oleh empat faktor psikologi utama yaitu motivasi, persepsi, pembelajaran, serta keyakinan dan sikap. ${ }^{14}$

1) Motivasi

Ahli psikologi telah mengembangkan teori motivasi manusia, terdapat tiga teori yang paling dikenal, yaitu:

a. Teori Motivasi Freud. Freud mengansumsikan bahwa kekuatan psikologis riil yang membentuk perilaku orang sebagian besar bersifat tidak sadar. Freud melihat seseorang menaan banyak keinginan dalam proses 215.

${ }^{14}$ Philip Kotler, Manajemen Pemasaran, hal, pertumbuhan dan menerima aturan-aturan social.

b. Teori Motivasi Maslow, Abraham Maslow berusaha menjelaskan mengapa orang-orang terdorang oleh kebutuhan-kebutuhan tertentu pada waktu tertentu.

c. Teori Motivasi Herzberg. Frederick Herzberg telah mengembangkan sebuah teori motifasi dua faktor, yang membedakan antara dissatisfiers (faktor yang menyebabkan ketidakpuasan) dan satisfies (faktor yang menyebabkan kepuasan).

2) Persepsi

Seseorang yang termotivasi adalah siap untuk bertindak. Bagaimana seseorang benarbenar bertindak dipengaruhi oleh persepsi dia mengenai situasi tertentu.

3) Pengetahuan

Pengetahuan menjelaskan perubahan dalam perilaku suatu individu yang berasal dari pengalaman.

4) Kepercayaan dan Sikap Pendirian 
Suatu kepercayaan adalah pikiran deskriptif yang dianut seseoarang melalui satu hal. Suatu pendirian menjelaskan evaluasi kognitif yang mengntungkan atau tidak menguntungkan, perasaan emosional,dan kecenderungan yang mapan dari seseorang terhadap suatu obyek atau ide. ${ }^{15}$

\section{Strategi pemasaran}

Strategi pemasaran merupakan hal yang sangat penting bagi perusahaan dimana strategi pemasaran merupakan suatu cara mencapai tujuan dari sebuah perusahaan. Hal ini juga didukung oleh pendapat Swastha "Strategi adalah serangkaian rancangan besar yang menggambarkan bagaimana sebuah perusahaan harus beroperasi untuk mencapai tujuannya. ${ }^{16}$ Sehingga dalam menjalankan usaha kecil khususnya diperlukan adanya pengembangan melalui strategi pemasarannya. Adapun strategi pemasaran meliputi:

a. Tujuan pemasaran

$\begin{array}{lr}\text { 1. Konsumen } & \text { potensial } \\ \text { mengetahui secara } & \text { detail } \\ \text { produk yang kita hasilkan dan } \\ \text { perusahaan } \\ \text { menyediakan }\end{array}$

15 Philip kotler, Analisis Perencanaan Implementasi dan Pengendalian, salemba empat, jakarta, 1995, 202-203.

${ }^{16}$ William J. Stanton, Prinsip Pemasaran, Alih Bahasa Wilhelmus W. Bokowatun, Erlangga, Jakarta, 1991, hlm. 5 permintaan mereka atas produk yang dihasilkan.

2. Perusahaan dapat menjelaskan secara detail semua kegiatan yang berhubungan dengan pemasaran. Kegiatan pemasaran ini meliputi berbagai kegiatan, mulai dari penjelasan mengenai produk, desain produk, promosi produk, pengiklanan produk, komunikasi kepada konsumen, sampai pengiriman produk agar sampai ke tangan konsumen secara cepat.

3. Mengenal dan memahami konsumen sedemikian rupa sehingga produk cocok dengannya dan dapat terjual dengan sendirinya.

b. Faktor-faktor yang mempengaruhi strategi pemasaran Pada umumnya kegiatan pemasaran berkaitan dengan koordinasi beberapa kegiatan bisnis. Strategi pemasaran ini dipengaruhi oleh:

1. Faktor mikro, yaitu perantara pemasaran, pemasok, pesaing dan masyarakat

2. Faktor makro, yaitu demografi/ekonomi, politik/hukum, teknologi/fisik dan sosial/budaya.

c. Hal-hal yang perlu diperhatikan oleh pemasar (penjual).

1. Produk yang bermutu (product) Kebijakan mengenai produk atau jasa meliputi jumlah barang/jasa yang akan ditawarkan perusahaan, 
pelayanan khusus yang ditawarkan perusahaan guna mendukung penjualan barang dan jasa, dan bentuk barang ataupun jasa yang ditawarkan. produk merupakan elemen yang paling penting. Sebab dengan inilah perusahaan berusaha untuk memenuhi kebutuhan dan keinginan dari konsumen. namun keputusan itu tidak berdiri sebab produk/jasa sangat erat hubungannya dengan target market yang dipilih.

2. Harga yang kompetitif (price)

Setiap perusahaan selalu mengejar keuntungan guna kesinambungan produksi. Keuntungan yang diperoleh ditentukan pada penetapan harga yang ditawarkan. Harga suatu produk atau jasa ditentukan pula dari besarnya pengorbanan yang dilakukan untuk menghasilkan jasa tersebut dan laba atau keuntungan yang diharapkan. Oleh karena itu, penentuan harga produk dari suatu perusahaan merupakan maslah yang cukup penting, karena dapat mempengaruhi hidup matinya serta laba dari perusahaan.

Kebijakan harga erat kaitannya dengan keputusan tentang jasa yang dipasarkan. Hal ini disebabkan harga merupakan penawaran suatu produk atau jasa. Dalam penetapan harga, biasanya didasarkan pada suatu kombinasi barang/jasa ditambah dengan beberapa jasa lain serta keuntungan yang memuaskan. Berdasarkan harga yang ditetapkan ini konsumen akan mengambil keputusan apakah dia membeli barang tersebut atau tidak. Juga konsumen menetapkan berapa jumlah barang/jasa yang harus dibeli berdasarkan harga tersebut. Entunya keputusan dari konsumen ini tidak hanya berdasarkan pada harga semata, tetapi banyak juga faktor lain yang menjadi pertimbangan, misalnya kualitas dari barang atau jasa, kepercayaan terhadap perusahaan dan sebagainya.

\section{Hendaknya}

setiap

perusahaan dapat menetapkan harga yang paling tepat, dalam arti yag dapat memberikan keuntungan yang paling baik, baik untuk jangka pendek maupun untuk jangka panjang.

3. Tempat yang strategis atau saluran distribusi (place)

Yang tidak boleh diabaikan dalam langkah memperlancar arus barang/jasa adalah memilih saluran distribusi (channel of distribution/tempat). Maslah memilih saluran distribusi/ tempat adalah masalah yang berpengaruh bagi merketing, karena kesalahan dalam memilih dapat menghambat bahkan macetnya usaha 
penyaluran produk/jasa dari produsen kekonsumen.

4. Promosi yang gencar (promotion).

Aspek yang berhubungan dengan berbagai usaha untuk memberikan informasi pada pasar tentang produk/jasa yang dijual, tempat dan saatnya. Ada beberapa cara menyebarkan informasi ini, antara lain periklanan (advertising), penjualan pribadi (personal selling), promosi penjualan (sales promotion) dan publisitas (publicity).

a) periklanan (advertising)

merupakan alat utama bagi pengusaha untuk mempengaruhi

konsumennya. Periklanan ini dapat dilakukan oleh pengusaha lewat surat kabar, radio, majalah, bioskop, televisi, ataupun dalam bentuk poster-poster yang dipasang dipinggir jalan atau tempat-tempat yang strategis.

b) penjualan pribadi (personal selling)

merupakan kegiatan perusahaan untuk melakukan kontak langsung dengan calon konsumennya. Dengan kontak langsung ini diharapkan akan terjadi hubungan atau interaksi yang positif antara pengusaha dengan calon konsumennya itu. Yang termasuk dalam personal selling adalah door to door selling, mail order, telephone selling, dan direct selling.

c) promosi penjualan (salles promotion)

merupakan kegiatan perusahaan untuk menjajakan produk yang dipasarkannya sedemikian rupa sehingga konsumen akan mudah untuk melihatnya dan bahkan dengan cara penempatan dan pengaturan tertentu, maka produk tersebut akan menarik perhatian konsumen.

d) publisitas (publicity) merupakan cara yang biasa digunakan juga oleh perusahaan untuk membentuk pengaruh secara tidak langsung kepada konsumen, agar mereka menjadi tahu, dan menyenangi produk yang dipasarkannya, hal ini berbeda dengan promosi, dimana didalam melakukan publisitas perusahaan tidak melakukan hal yang bersifat komersial. Publisitas merupakan suatu alat promosi yang mampu membentuk opini masyarakat secara tepat, sehingga sering disebut sebagai usaha untuk 
mensosialisasikan atau memasyarakatkan.

d. Hal-hal yang perlu diperhatikan dari sudut pandang konsumen :

1. Kebutuhan dan keinginan konsumen (customer needs and wants),

2. Biaya konsumen (cost to the customer)

3. Kenyamanan (convenience), dan

4. Komunikasi (comunication).

5. Teori pelayanan

Kualitas pelanggan (servqual) dibangun atas adanya perbandingan antara dua factor utama yaitu persepsi pelangan atas layanan yang nyata akan mereka terima (peceived service) dengan layanan yang sesungguhnya diharapkan/diinginkan (expected service). ${ }^{17}$

Dalam salah satu studi mengenai servqual pasuraman (1988) yang melibatkan 800 pelanggan (yang terbagi dalam empat perusahaan) berusia 25 tahun ke atas, disimpulkan bahwa terdapat lima dimensi servqual sebagai berikut: ${ }^{18}$

a. Tangibles, atau bukti fisik yitu kemampuan suatu perusahaan dalam menunjukkan eksistensi kepada pihak eksternal. Penampilan dan kemampuan sarana dan prasarana fisik Jasa, hal. 148.

${ }^{17}$ Rambat Lupiyoadi, Manajemen Pemasaran

${ }^{18}$ Ibid., hlm. 148-149. perusahaan dan keadaan lingkungan sekitarnya adalah bukti nyata dari pelayanan yang diberikan oleh pemberi jasa. Yang meliputi fasilitas fisik (gedung, gudang dan lain sebagainya), perlengkapan dan peralatan yang digunakan (teknologi), serta penampilan pegawainya.

b. Reability, atau keandalan yaitu kemampuan perusahaan untuk memberikan pelayanan sesuai yang dijanjikan secara akurat dan terpercaya. Kinerja harus sesuai dengan harapan pelanggan yang berarti ketepatan waktu, pelayanan yang sam untuk semua pelanggan tanpa kesalahan, sikap yang simpatik, dan dengan akurasi yang tinggi.

c. Responsiveness, atau ketanggapan yaitu suatu kemauan untuk membantu dan memberikan pelayanan yang cepat (responsif) dan tepat kepada pelanggan, dengan penyampaian informasi yang jelas. Membiarkan konsumen menunggu tanpa adanya suatu alasan yang jelas menyebabkan persepsi yang negative dalam kualitas pelayanan.

d. Assurance, atau jaminan dan kepastian yaitu pengetahuan, kesopansantunan, dan kemampuan para pegawai perusahaan untuk menumbuhkan rasa percaya para pelanggan kepada perusahaan.

e. Empathy, yaitu memberikan perhatian yang tulus dan bersifat individual atau pribadi yang diberikan kepada para pelanggan 
dengan berupaya memahami keinginan konsumen. Di mana suatu perusahaan diharapkan memiliki pengertian dan pengetahuan tentang pelanggan, memahami kebutuhan pelanggan secara spesifik, serta memiliki waktu pengoperasian yang nyaman bagi pelanggan.

6. Kerangka pemasaran dalam islam

Kerangka pemasaran dalam bisnis islam ${ }^{19}$

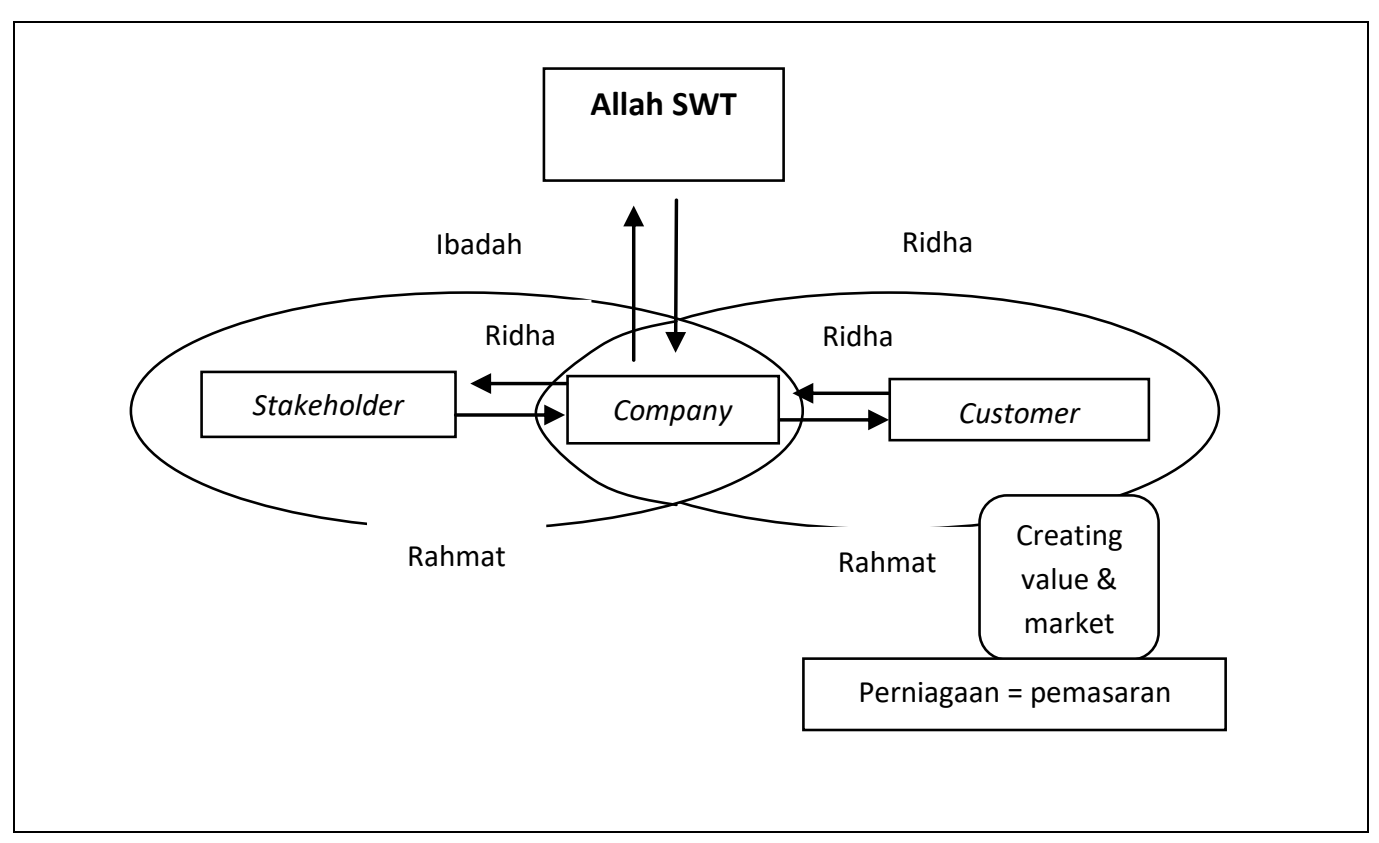

${ }^{19}$ Muhammad, 2004. Etika Bisnsis Islam, Akademi Manajemen Perusahaan YKPN, Yogyakarta, hal. 100. 
Gambar diatas menunjukan bahwa kerangka pemasaran dalam bisnis islami sangat mengedepankan adanya konsep rahmat dan ridha, baik dari penjual pembeli, sampai dari Allah SWT. Dengan demikian, aktivitas pemasaran harus didasari pada etika dalam bauran pemasarannya. Sehubungan dengan ini dapat diklasifikasikan sebagai berikut:

1. Etika pemasaran dalam konteks produk

a. Produk yang halal dan thoyib

b. Produk yang berguna dan dibutuhkan

c. Produk yang berpotensi ekonomi atau benefit

d. Produk yang yang bernilai tambah tinggi

e. Dalam jumlah yang berskala ekonomi dan sosial

f. Produk yang dapat memuaskan masyarakat

2. Etika pemasaran dalam konteks harga

a. Beban biaya produksi yang wajar

b. Sebagai alat kompetisi yang sehat

c. Diukur dengan kemampuan daya beli masyarakat

d. Margin perusahaan yang layak

e. Sebagai alat daya tarik bagi konsumen
3. Etika pemasaran dalam konteks distribusi

a. Kecepatan dan ketepatan waktu

b. Keamanan dan keutuhan barang

c. Sarana kmpetisi memberikan pelayanan kepada masyarakat

d. Konsumen mendapat pelayanan tepat dan cepat

4. Etika pemasaran dalam konteks promosi

a. Sarana memperkenalakan barang

b. Informasi kegunaan dan kualifikasi barang

c. Sarana daya tarik barang terhadap konsumen

d. Informasi fakta yang ditopang kejujuran.

Dalam kerangka islam, etika dalam pemasaran tentunya perlu didasari pada nilai-nilai yang dikandung Al-qur'an dan hadist nabi. Beberapa ayat dan hadis nabi yang dapat dijadikan pijakan etika dalam pemasaran diantaranya:

1. Perhatikan oleh mu sekalian perdangangan, sesunguhnya didunia perdagangan itu ada sembilan dari sepuluh pintu rezeki (H.R Ahmad)

2. Surat annisa ayat : 29

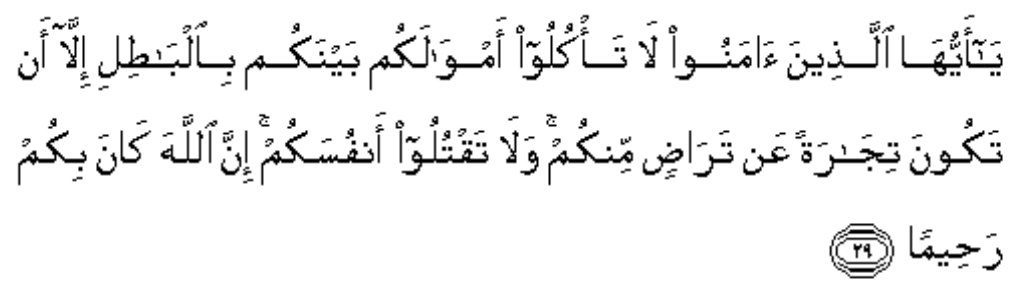


"Hai orang-orang yang beriman, janganlah kamu saling memakan harta sesamamu dengan jalan yang batil, kecuali dengan jalan perniagaan yang berlaku dengan suka sama-suka di antara kamu. dan janganlah kamu membunuh dirimu Sesungguhnya Allah adalah Maha Penyayang kepadamu”.

3. Barang siapa yang memelihara silaturahmi, maka Allah akan menganugerahkan rizki yang melimpah dan umur panjang.

Disamping itu, teladan rasulullah dalm berdagang kirannya dapat dijadikan acuan dalam memasarkan produk perdagangannya. Beberapa kiat dan etika rasulullah dalam mengembangkan citra dagangnya adalah sebagai berikut:

1. Penampilan Penampilan dagang rasulullah adalah tidak membohongi pelanggan, baik menyangkut besaran (kuantitas) maupun kualitas

$$
\text { "Apabila dilakukan }
$$
penjualan, katakan, tidak ada penipuan."

Surat Asy-syuaraa : 181-183


"Sempurnakanlah takaran dan janganlah kamu termasuk orang- orang yang merugikan, dan timbanglah dengan timbangan yang lurus, dan janganlah kamu merugikan manusia pada hak-haknya dan janganlah kamu merajalela di muka bumi dengan membuat kerusakan."

2. Pelayanan

Pelanggan yang tidak sanggup membayar kontan hendaknya diberi tempo untuk melunsinya. Selanjutnya, pengampunan (bila memungkinkan) hendaknya diberikan jika ia benar-benar tidak sanggup membayarnya

3. Persuasi 
Menjauhi sumpah yang berlebihan dalam menjual suatu barang

"sumpah dengan maksud melariskan barang dagnagan adalah penghapusan berkah." (HR. Bukhori Muslim).

4. Pemuasan

Hanya dengan kesepakatan bersama, dengan suatu usulan dan penerimaan, penjulan akan sempurna

"Hai orang yang beriman, janganlah kamu saling memakan harta sesamamu dengan jalan yang batil, kecuali dengan jalan perniagaan yang berlaku dengan suka sama-suka di antara kamu. dan janganlah kamu membunuh dirimu Sesungguhnya Allah adalah Maha Penyayang kepadamu." (QS. An-nisa :29).

"Kamu tidak boleh berpisah kecuali dengan kesepakatan bersama"20

D. Mempertahankan konsumen

1. Membangun relasi pelanggan

a. Pemasaran dasar

Menjual atau memasarkan produknya begitu saja.

b. Pemasaran reaktif

Menjual produknya dan menampung sagala komentar, keluhan dan saran.

c. Pemasaran tanggung jawab

Menanyakan kepada pelanggan apakah produknya sudah memenuhi harapan dan meminta saran perbaikan produk dan menanyakan apa saja kekecewaannya.
d. Pemasaran proaktif
Menghubungi pelanggan dari waktu kewaktu untuk menanyakan penggunaan produk yang sudah diperbaiki atau produk baru.
e. Pemasaran kemitraan

$\begin{array}{lrr}\text { Perusahaan } & \text { bekerja } & \text { sama } \\ \text { dengan } & \text { pelanggan } & \text { untuk } \\ \text { membantu } & \text { memperbaiki } \\ \text { kinerjanya } & & \end{array}$

2. Membentuk ikatan pelanggan yang kuat

Perusahaan yang ingin membentuk ikatan pelanggan yang kuat perlu mengikuti dasar-dasar berikut:

a. Dapatkan partisipasi lintas departemen dalam merencanakan dan mengelola kepuasan pelanggan dan proses retensi.

b. Padukan suara pelanggan dalam semua keputusan bisnis.

c. Ciptakan produk, pelayanan dan pengalaman yang unggul bagi pasar sasaran

d. Organisasi dan mudahkan akses basis data informasi tentang kebutuhan, kelebih sukaan, kontak, frekuensi pembeli dan keputusan pelanggan.

e. Mudahkan para pelanggan untuk menjangkau personalia perusahaan yang tepat guna mengungkapkan kebutuhan, persepsi dan keluhan mereka.

f. Jalankan program pemberian imbalan guna mengakui

${ }^{20}$ Ibid., hal. 102. 
karyawan yang prestasinya luar biasa. $^{21}$

\section{PENUTUP}

Manajeman pemasaran Menurut Kotler dan Armstrong, berasal dari dua kata yaitu manajemen dan pemasaran. pemasaran adalah analisis, perencanaan, implementasi, dan pengendalian dari program-program yang dirancang untuk menciptakan, membangun, dan memelihara pertukaran yang menguntungkan dengan pembeli sasaran untuk mencapai tujuan perusahaan. Sedangkan manajemen adalah proses perencanaan (Planning), pengorganisasian (organizing) penggerakan (Actuating) dan pengawasan (controling).

Bergitu pula manajemen pemasaran berdasarkan maqasid syariah adalah sebagai analisis, perencanaan, penerapan, dan pengendalian program yang dirancang untuk menciptakan, membangun, dan mempertahankan pertukaran yang menguntungkan dengan pasar sasaran dengan maksud untuk mencapai tujuantujuan organisasi dengan memperhatikan nilai-nilai syariah yang berupa maslahah, keadilan dan mengedepankan adanya konsep rahmat dan ridha, baik dari penjual dan pembeli, sampai dari Allah SWT.
Dan dalam konteks ekonomi islam manajemen pemasaran harus mempunyai etika, yang berupa:

1. Etika pemasaran dalam konteks produk, bahwasannya produk harus: a) Produk yang halal dan thoyib, b) Produk yang berguna dan dibutuhkan,c) Produk yang berpotensi ekonomi atau benefit, d) Produk yang yang bernilai tambah tinggi, e) Dalam jumlah yang berskala ekonomi dan sosial, f) Produk yang dapat memuaskan masyarakat.

2. Etika pemasaran dalam konteks harga, yaitu : a) Beban biaya produksi yang wajar, b) Sebagai alat kompetisi yang sehat, c) Diukur dengan kemampuan daya beli masyarakat, d) Margin perusahaan yang layak, e) Sebagai alat daya tarik bagi konsumen

3. Etika pemasaran dalam konteks distribusi, yaitu: a) Kecepatan dan ketepatan waktu, b) Keamanan dan keutuhan barang, c) Sarana kmpetisi memberikan pelayanan kepada masyarakat, d) Konsumen mendapat pelayanan tepat dan cepat.

4. Etika pemasaran dalam konteks promosi, yaitu: a) Sarana memperkenalkan barang, b) Informasi kegunaan dan kualifikasi barang, c) Sarana daya tarik barang terhadap konsumen, d) Informasi fakta yang ditopang kejujuran.
${ }^{21}$ Philip kotler, (2005). Manajemen Pemasaran, edisi 11, alih bahasa Benyamin Molan, PT Intan Sejati Klaten, Jakarta, ha, 87-88. 


\section{DAFTAR PUSTAKA}

Asafri Jaya, (1996). Konsep Maqashid al-Syari'ah Menurut al-Syathibi, Raja Grafindo Persada, Jakarta.

Habib Nazir dan Muhammad Hasanuddin, (2008). Ensiklopedi Ekonomi dan Perbankan Syariah, Kafa Publishing, Bandung.

Heri Sudarsono, (2007). Bank dan Lembaga Keunagan Syariah, Deskripsi Dan Ilustrasi, edisi 2, Ekonisia, Yogyakarta.

Muhammad, (2004). Etika Bisnis Islam, Akademi Manajemen Perusahaan YKPN, Yogyakarta.

Philip Kotler, (1995). Analisis, Perencanaan, Implementasi Dan Pengendalian, Alih Bahasa: ancella anitawati hermawan salemba empat, jakarta.
Philip Kotler, (2005). Manajemen Pemasaran, edisi 11, alih bahasa Benyamin Molan, PT Intan Sejati Klaten, Jakarta.

Rambat Lupiyoadi, (2001). Manajemen Pemasaran Jasa, Salemba Empat, Jakarta.

Rahman Ritonga dkk, (2001). Ensiklopedi Hukum Islam, PT Intermasa, Jakarta.

Wahbah al-Zuhaili, (1986). Ushul alFigh al-Islami, Dar al-Fikr, Beirut.

William J. Stanton, (1991). Prinsip Pemasaran, Alih Bahasa Wilhelmus W. Bokowatun, Erlangga, Jakarta.

http://ciku.typepad.com/blog/2009/12/d efinisi-pemasaran-danmanajemen-pemasaran.html.

http://salmanitb.com/2010/02/prinsipprinsip-dasar-ekonomi-syariah/ 